\title{
As origens do "vale-tudo" na cidade de Curitiba-PR: memórias sobre identidade, masculinidade e violência
}

\author{
Daniella de Alencar Passos* \\ Rodrigo Cribari Prado** \\ Wanderley Marchi Júnior *** \\ André Mendes Capraro ****
}

\begin{abstract}
Resumo: O presente artigo objetiva analisar como professores (mestres) e ex-lutadores de modalidades de lutas e artes marciais apresentam suas memórias acerca dos primórdios da prática que ficou conhecida como "vale-tudo" em Curitiba. Por meio dos procedimentos teóricos da História Oral foi possível perceber que os fragmentos memoriais analisados não se restringem à interpretação sobre as origens dessa prática, pois também são atravessados por discursos relativos ao processo de construção da identidade e testes constantes de virilidade. Conclui-se que a memória estabelecida e esse ethos masculino tem como elemento central a violência concreta e simbólica - que acompanha a formação do lutador. Palavras-chave: "vale-tudo". Memória. Identidade. Masculinidade. Violência.
\end{abstract}

\section{INTRODUÇÃo}

No início da década de 1990 a cidade de Curitiba foi palco de uma série de contundentes confrontos físicos entre praticantes de lutas, sobretudo entre representantes de modalidades como

\footnotetext{
*Pós-graduação em Educação Física, Universidade Federal do Paraná, Curitiba, PR, Brasil. E-mail: daniapassos@yahoo.com.br

**Mestre em Educação Física pela Universidade Federal do Paraná, Curitiba, PR, Brasil. E-mail: rcprado@hotmail.com

***Pós-graduação em Educação Física, Universidade Federal do Paraná, Curitiba, PR, Brasil. E-mail:wmarchijr@gmail.com

****Pós-graduação em Educação Física, Universidade Federal do Paraná, Curitiba, PR, Brasil. E-mail: andrecapraro@onda.com.br
} 
o Muay Thai ${ }^{1}$ e a Capoeira ${ }^{2}$. Tais confrontos ocorriam em vias públicas, casas noturnas e em qualquer espaço onde houvesse a oportunidade desses lutadores demonstrarem sua superioridade técnica e, ao mesmo tempo, colocar à prova sua virilidade. Nesse sentido, Edison Luis Gastaldo e Adriana Andrade Braga (2011), em um estudo etnográfico sobre praticantes de Kickboxing da cidade de Porto Alegre- RS, explicam que:

A prática de disputas e competições pode ser considerada uma característica bastante generalizada do ethos masculino. [...] Em culturas as mais diversas, a afirmação social do 'ser homem' passa pela disputa com outros homens, seja do modo mais direto, em uma luta corpo a corpo, seja por vias mais sutis, como desafios verbais, torneios de insultos ou apostas em rinha de galos (GASTALDO; BRAGA, 2011, p. 880).

Como as principais querelas ocorridas na Curitiba da década de 1990 foram protagonizadas por praticantes da principal academia de Muay Thai na época - que posteriormente tornou-se uma grande formadora de lutadores de "Vale-tudo"3 - e por capoeiristas ligados a um dos introdutores da Capoeira Angola ${ }^{4}$ na capital paranaense (início da década de 1970) foi realizado um acordo entre os líderes das duas academias. A finalidade era moderar os confrontos entre seus atletas, já que estavam se tornando cada vez mais frequentes e violentos. Tratava-se de uma forma de amenizar tais embates por meio da realização de um evento que explorasse a rivalidade já existente entre os atletas e, ao mesmo tempo, uma possibilidade

${ }^{1} \mathrm{O}$ Muay Thai ou Boxe Tailandês é uma arte marcial de origem oriental também conhecida por "luta das oito armas", uma vez que envolve golpes de contato que utilizam ambos os punhos, cotovelos, joelhos e canelas.

${ }^{2} \mathrm{~A}$ Capoeira pode ser considerada uma prática de caráter híbrido,pois contém elementos de dança, jogo e luta.

${ }^{3}$ Nos torneios de "Vale-tudo" (conhecidos também como interestilos ou freestyle) o objetivo era confrontar representantes de diferentes modalidades de luta afim de provar qual a mais eficiente e não, como o próprio termo sugere, que valia qualquer tipo de golpe durante a luta, ou seja, havia uma carência de regras.

${ }^{4} \mathrm{~A}$ Capoeira denominada "Angola" surge em contestação a outro estilo de Capoeira, conhecida como "Regional". Os principais representantes dos dois estilos foram Mestre Pastinha (Capoeira Angola) e Mestre Bimba (Capoeira regional).

Movimento, Porto Alegre, v. 20, n. 3, p. 1153-1173, jul./set. de 2014. 
de promover suas respectivas modalidades. O próprio mestre da referida academia de Muay Thai envolvida neste desafio admitiu a sua participação na realização do primeiro evento de grande porte protagonizado por praticantes de diferentes modalidades, explicando:

[...] o "Vale-tudo" começou aqui porque um aluno de Muay Thai da minha academia se desentendeu com um aluno de Capoeira e por sugestão dos capoeiristas é que escolheram cinco representantes e cinco do Muay Thai e a gente fez um desafio no ginásio do Círculo Militar. (Entrevistado 8 mestre de Muay Thai - entrevista cedida em 19 nov. 2012).

$\mathrm{Na}$ visão de praticamente todos os entrevistados que participaram da pesquisa ${ }^{5}$ que originou este artigo, tratava-se de um "acerto de contas" entre rivais, mas também uma forma inteligente de negócio, como evidencia a narrativa a seguir:

[...] ao invés deles pegarem [e lutarem] dentro de uma academia [para] ver quem que era o melhor, quem era o mais forte, tirar [e] resolver as desavenças que havia, eles olharam pro lado comercial: por que a gente não promove isso num evento, em vez da gente fazer isso aqui pra trinta pessoas dentro da academia, a gente faz pra três mil pessoas no Círculo Militar, e foi aí que [tudo] começou. (Entrevistado 10 - ex-professor de Luta Livre e ex-lutador de "Vale-tudo" - entrevista cedida em 23 nov. 2012).

Esse confronto institucionalizado entre capoeiristas e praticantes de Muay Thai ocorreu no dia 29 de agosto de 1993, e ficou conhecido como o marco inicial do "Vale-tudo" na capital paranaense. Mais do que dados factuais, o que se busca por meio das memórias apresentadas ao longo deste artigo, é aquilo que o autor Michael Pollak (1989) denominou de um "trabalho de

\footnotetext{
${ }^{5}$ Foram realizadas dez entrevistas com sujeitos envolvidos diretamente com as Artes Marciais na cidade de Curitiba-PR, sobretudo com as modalidades e eventos apontados ao longo deste texto.
}

Movimento, Porto Alegre, v. 20, n. 3, p. 1153-1173, jul./set. de 2014. 
enquadramento da memória". Ou seja, como se formaram tais memórias sobre as origens do "Vale-tudo" em Curitiba, e quais são os sentidos e significados subjacentes em tais memórias. Nesse sentido, é possível identificar nos fragmentos narrativos selecionados percepções e interpretações sobre o processo de forjadura pelo qual o lutador deve passar antes de ser aceito por seu grupo, mas que é ao mesmo tempo um processo formador de identidades, tanto individuais, quanto coletivas. Além disso, também emergem em tais narrativas (memórias), noções e entendimentos sobre masculinidade e virilidade que são parte constituinte da identidade do ethos próprio dos lutadores.

Outras contribuições teóricas importantes já foram registradas, não especificamente sobre o início da prática do "Vale-tudo" na cidade em questão, mas sobre o processo de formação da identidade de lutadores (de diferentes modalidades). Como exemplos, podem ser citados os trabalhos de Gastaldo (1995); Cecchetto (2004); Nunes (2004); Mayer (2005); Polato (2006); Teixeira (2008), entre outros.

Diante do exposto anteriormente, questiona-se: quais são e como se manifestam as memórias e os discursos de professores (mestres) e ex-lutadores de diferentes modalidades de lutas e artes marciais que participaram dos primórdios da prática que ficou conhecida como "Vale-tudo" na cidade de Curitiba-PR?

A fim de responder tal questão-problema, a metodologia empregada no processo de captação e processamento das entrevistas realizadas é a da própria História Oral (Alessandro Portelli, 2010a, 2010b, 1996; e Verena Alberti, 2005). Os discursos (memórias) dos entrevistados foram analisados a partir de conceitos de diferentes campos disciplinares (História, História Oral, Sociologia, Antropologia e Estudos de Gênero', pois há nas narrativas uma série de noções que se sobrepõem e que demandam diferentes perspectivas teóricas. Para análise das noções de memória e identidade (individual e de grupo) foram adotados textos de Michael Pollak (1989, 1992), enquanto que os autores Edson Luiz 
As origens do "vale-tudo" na cidade de ...

Gastaldo (1995); Robert Connel (1997); Guacira Lopes Louro (2001) e Fátima Regina Cecchetto (2004) auxiliaram na reflexão sobre violência, identidade e masculinidade. Além disso, algumas das categorias interpretativas - especialmente o conceito de habitus e de ethos de classe - de Pierre Bourdieu (1983) também foram aqui empregadas.

Este é um artigo que propõe uma interpretação sobre interpretações. Nessa perspectiva é importante considerar o significativo número de camadas que se sobrepõem e ao mesmo tempo se amalgamam gerando sempre novas interpretações. A esse respeito, o historiador oral Alessandro Portelli afirma que a memória:

[...] é menos o 'testemunho' de eventos e mais uma 'construção' feita de palavras por meio da cooperação de editores, entrevistadores, testemunhas e narradores, cada um deles buscando através da linguagem, dar forma e significado à experiência e à memória (PORTELLI, 2010a, p.187).

\section{PROCESSO DA FORMAÇÃO DA IDENTIDADE INDIVIDUAL E COLETIVA ENTRE OS PRATICANTES DE VALE-TUDO}

Durante o final da década de 1970 a cidade de Curitiba foi palco do surgimento de uma nova modalidade de arte marcial que rapidamente se popularizou e revelou atletas de renome nacional e internacional: o Muay Thai também conhecido como Boxe Tailandês. A modalidade, ainda então desconhecida, desembarcou no país através da experiência curitibana e só depois se difundiu para outros estados como, o Rio de Janeiro e São Paulo. Segundo a narrativa dos entrevistados, o indivíduo responsável pela introdução da referida modalidade foi o então faixa-preta de Taekwondo Nélio Borges de Souza, conhecido como Nélio "Naja".

A trajetória vitoriosa de vários atletas curitibanos que adquiriram destaque nacional e internacional nos eventos de

Movimento, Porto Alegre, v. 20, n. 3, p. 1153-1173, jul./set. de 2014. 
"Vale-tudo" e posteriormente de Artes Marciais Mistas ${ }^{6}$ é apontada como decorrência desse pioneirismo do Muay Thai na cidade. No depoimento de alguns entrevistados:

Curitiba hoje é uma vitrine do "Vale-tudo". É uma fábrica de fazer lutadores. Uma coisa que surgiu sem querer e hoje temos vários lutadores que nem o Anderson [Silva], conhecido no mundo inteiro. (Entrevistado 4 - mestre de Capoeira - entrevista cedida em 07 nov. 2012).

[...] Curitiba se criou porque o DNA do MMA caiu em Curitiba.. (Entrevistado 1 - ex-praticante de Muay Thai - entrevista cedida em 21 set. 2012).

Quando eu comecei a treinar, já existia uma estrutura criada, foi feito um alicerce de sabedoria, da ciência do Muay Thai e, graças a Deus, treinei nessa época. (Entrevistado 3 - mestre de Muay Thai - entrevista cedida em 20 out. 2012).

Eu já cansei de ir para eventos na época que eu competia e quando o pessoal sabia que eu era de Curitiba vinham tirar foto comigo antes do evento e nem sabiam se eu lutava bem. Devido a importância que temos, onde o Muay Thai surgiu foi aqui, é o carro chefe dos lutadores de Curitiba. (Entrevistado 5 - ex-lutador e mestre de Muay Thai - entrevista cedida em 08 nov. 2012)

Esse Muay Thai que levou vários lutadores a serem campeões foi porque eles têm um Muay Thai muito bem afiado. (Entrevistado 8 - mestre de Muay Thai - entrevista cedida em 19 out. 2012).

Os termos utilizados: "fábrica", "DNA", "ciência", "base" e "estrutura" demonstram que os indivíduos que se envolveram com a modalidade nesse período de introdução

${ }^{6} \mathrm{O}$ Mixed Martial Arts, mais conhecido pela sua sigla MMA (em português, Artes Marciais Mistas), é uma modalidade que engloba técnicas de diversas lutas como o Jiu-jitsu, Muay Thai, Luta Livre, Boxe, Judô, Capoeira, Taekwondo, dentre outras. Apesar de existir uma conexão entre "Vale-tudo" e MMA, essa relação não pode ser caracterizada como de continuidade, tampouco linear.

Movimento, Porto Alegre, v. 20, n. 3, p. 1153-1173, jul./set. de 2014. 
e posterior desenvolvimento atribuem à prática características como tradição e evolução. O sucesso dos lutadores ${ }^{7}$ locais em competições internacionais seria em decorrência da formação oriunda da experiência curitibana com o Muay Thai e a aquisição de um estilo de luta e treinamento próprios. Além disso, lentamente, surgiriam alguns eventos ${ }^{8}$ de combate na própria cidade, considerados dentre os principais do cenário nacional na época, tendo como parâmetros os quesitos público e nível técnico.

Outros aspectos que também teriam levado os lutadores curitibanos a se tornarem campeões, a "chegarem lá", foi atribuído a uma postura e um método de treinamento bastante específicos:

A técnica da academia que tem esse Muay Thai bem agressivo e misturado com a filosofia da academia que os técnicos passam para os atletas de fazer com que eles sejam aguerridos, que vão até o final da luta, é por causa disso. Os treinos também são muitos duros. [...] Uns acham que era arrogância, mas foi bom. [...] essa autoconfiança eu acho positivo para o atleta, ele entra com a obrigação não só por ele, mas você sabe que tem uma equipe por trás. [...] Eu acho que muitos que não têm essa filosofia acabam se entregando mais fácil. (Entrevistado 8 - mestre de Muay Thai entrevista cedida em 19 nov. 2012).

A aceitação e o enfrentamento de desafios são vistos como um dos pilares da masculinidade (GASTALDO; BRAGA, 2011). O lutador, nesse contexto, entra na luta com a obrigação de vencer, independente das consequências. A autoconfiança, e em alguns casos uma postura arrogante, é parte constituinte da filosofia própria do grupo e evidencia a pressão sofrida, sobretudo por parte de seus companheiros em situações de competição.

\footnotetext{
${ }^{7}$ Alguns dos nomes das Artes Marciais Mistas de destaque no cenário internacional e que tiveram sua formação no Muay Thai curitibano foram: José "Pelé" Landy, Wanderlei Silva, Murilo "Ninja" Rua, Assuério Silva, Maurício "Shogun" Rua, Anderson "The Spider" Silva e Cristiane "Cyborg" Justino.

${ }^{8}$ Street Fighter (1996, 1997, 1998); Meca World Vale-tudo iniciou em 1999 e teve nove edições; a partir de 2003 surgiu o Storm Samurai e até 2014 contabilizou quinze edições.
}

Movimento, Porto Alegre, v. 20, n. 3, p. 1153-1173, jul./set. de 2014. 
Na construção da masculinidade o aprendizado de uma técnica de luta é parte integrante da formação do corpo, principalmente a partir das situações de competição, nas quais a postura agressiva em relação ao oponente está associada à virilidade ${ }^{9}$, à força e à masculinidade, conforme indica Louro:

[...] a competição é inerente à maioria das práticas esportivas. Não se pode negar que ser o melhor, no esporte, pode representar, especialmente para um menino ou um jovem, um valorizado símbolo de masculinidade (LOURO, 2001, p. 75).

Assim, "demonstrar tenacidade e determinação seriam os aspectos exigidos dos homens ao buscar a vitória no combate" (CECCHETTO, 2004, p. 142), valores também conhecidos como "garra", "dar o sangue", ser "guerreiro". Neste processo de tornar-se (e mostrar-se) lutador ocorre a apropriação do que Wacquant (2002, p. 34) chamou de habitus pugilístico, que por sua vez caracteriza-se tanto na perspectiva individual quanto coletiva conforme o indivíduo:

[...] apropria-se, por impregnação progressiva, de um conjunto de mecanismos corporais e de esquemas mentais tão estreitamente imbricados que eles apagam a distinção entre o físico e o espiritual, entre o que emerge das capacidades atléticas e o que diz respeito às faculdades morais e à vontade (WACQUANT, 2002, p. 34).

A hipervalorização dessa postura aguerrida, capaz de agredir, como fruto de uma construção identitária tanto dos atletas quanto de seu grupo possibilita a veiculação de status e de relações de poder que revelam significados de pertencimento e afirmação.

Uma academia de artes marciais, lutas e esportes de combate ${ }^{10}$

\footnotetext{
${ }^{9} \mathrm{~A}$ virilidade para o sociólogo Pierre Bourdieu pode ser compreendida "[...] tanto como a capacidade reprodutiva sexual, quanto como aptidão para o confronto e o exercício da violência" (BOURDIEU, 2007a, p.63).

${ }^{10} \mathrm{~A}$ denominação Modalidades Esportivas de Combate implica uma configuração das práticas de lutas, das artes marciais e dos sistemas de combate sistematizados em manifestações culturais modernas, orientadas a partir das decodificações propostas pelas instituições esportivas. Aspectos e conceitos como competição, mensuração, aplicação de conceitos científicos, comparação de resultados, regras e normas codificadas e institucionalizadas, maximização do rendimento corporal e espetacularização da expressão corporal são alguns exemplos dessa transposição moderna de
}

Movimento, Porto Alegre, v. 20, n. 3, p. 1153-1173, jul./set. de 2014. 
As origens do "vale-tudo" na cidade de ...

é, deste ponto de vista, um espaço masculino não apenas porque exige imensos sacrifícios dos corpos dos praticantes, ou porque estes, para ganharem o reconhecimento de seus companheiros, devem demonstrar um espírito "guerreiro" ao superar constantemente situações de dor, lesões, medo e desafios.

Ao se submeter e suportar os árduos treinamentos "daquela época", os entrevistados atribuem às suas experiências um sentimento de orgulho:

[...] Hoje Curitiba criou lutadores top porque o Muay Thai já existe há muito tempo aqui e vem sendo "mastigado" [facilitado]. Quem começou na década de 1980 passou para eles isso" mastigado" e sofreu muito. (Entrevistado 2 - exlutador e mestre de Muay Thai - entrevista cedida em 6 out. 2012).

Treinei até 1989, no tempo em que o chão ainda era de Paviflex, a luva era uma só e usávamos taquara pra calejar as canelas. (Entrevistado 1 ex-praticante de Muay Thai - entrevista cedida em 21 set. 2012).

Os que começam a treinar hoje não têm noção do que nós treinávamos nos anos 80. [...] era cotovelada, joelhada, era um negócio sinistro [...] E eu graças a Deus treinei nessa época. (Entrevistado 3 - mestre de Muay Thai entrevista cedida em 20 out. 2012).

O contexto de treinamentos "duros" na fase de introdução da modalidade, demonstra um sentimento nostálgico e, de certo modo, o que se treina hoje estaria "mastigado" (facilitado) devido ao processo de esportivização que a modalidade enfrentou ao longo do tempo. Essas circunstâncias de fabricação de corpos através dos rígidos treinamentos foram condições para que a modalidade pudesse chegar a um estágio de refinamento.

As experiências de treinamento foram constituindo simultaneamente um método corporal apurado, mas também

práticas seculares de "combate". (CORREIA; FRANCHINI, 2010, p.02).

Movimento, Porto Alegre, v. 20, n. 3, p. 1153-1173, jul./set. de 2014. 
um habitus próprio dos lutadores daquele período. A expressão habitus está sendo aqui empregada nos termos de Bourdieu (1998), que explica que o conjunto de disposições que passam a ser interiorizadas pelos praticantes podem ser compreendidas como "[...] princípios subjetivos de visão, categorias cognitivas através das quais os indivíduos veem e constroem o mundo como realidade significativa, viva" (BOURDIEU, 1998, p. 19).

Acompreensão da dor comoummeionecessárioeindispensável para o fortalecimento dos corpos pode ser interpretada como parte constituinte do habitus estruturado pelo grupo. Esse conjunto de referências e disposições orientadas para a ação é ressaltado como "[...] uma forma pré-reflexiva do corpo introjetar padrões culturais e experiências, transmutando-as em uma "política corporificada"" (BOURDIEU, 1998, p. 19).

Essas inscrições nos corpos dos indivíduos acontecem através da construção de capitais, como formas de investimentos muito particulares a partir da prática (lesões nas canelas, cortes no rosto, dentes quebrados, costelas fraturadas, etc.). Trata-se de uma forma de capitalização através da dor. Esse capital físico incorporado é uma forma de capital cultural adquirido com esforço e de modo pessoal, por meio de um contínuo processo de aprendizagem - de longa duração - e da acumulação de conhecimentos individuais.

A incorporação de um habitus sobre o que é ser masculino no processo de constituição de uma subjetividade masculina é tão enraizado em nossa sociedade que as diferenças passam a ser encaradas como naturais e imutáveis. Entretanto, tratar de masculinidade apenas como o contrário de feminilidade não faz com que aquela exista de fato, pois é possível detectar historicamente que em "[...] todas as sociedades existem registros culturais de gênero, mas nem todas têm o conceito de masculinidade." (CONNELL, 1997, p.35, tradução livre). Desse modo, o conceito masculino e as noções de masculinidade existem enquanto construções individuais e sociais atreladas a determinadas avaliações e normas

Movimento, Porto Alegre, v. 20, n. 3, p. 1153-1173, jul./set. de 2014. 
sociais, processos de socialização e estruturas e relações de poder formadas e transformadas na história e, portanto, “[...] é no âmbito das relações sociais que se constroem os gêneros" (LOURO, 2001, p.22).

Em geral, as práticas físicas voltadas ao desempenho corporal são associadas ao gênero masculino por serem um meio que possibilita a exibição da virilidade. Tal identificação com o gênero masculino ainda está amalgamada "[...] a uma espécie de escala em que se pode hierarquizar simbolicamente a masculinidade de um indivíduo em relação a outro" (GASTALDO; BRAGA, 2001, p.886). Pensando nessa polarização de gêneros e na hierarquização das masculinidades, é importante destacar alguns dos ritos que determinam esse processo demarcatório.

\section{COMO SE "FORJA" UM LUTADOR: A CONSTRUÇÃO DA MASCULINIDADE NAS ACADEMIAS E TAMBÉM NAS RUAS}

No micro-espaço pesquisado, a cidade de Curitiba, foi possível detectar que nos rituais atrelados às lutas, artes marciais e esportes de combate, de modo geral, há um simbolismo originado no domínio da virilidade masculina. Esses "ritos de iniciação" ocorridos no interior das academias seriam formas de distinção e ao mesmo tempo de formação da identidade masculina. Segundo Louro:

Em suas relações sociais, atravessadas por diferentes discursos, símbolos, representações e práticas, os sujeitos vão se construindo como masculinos ou femininos, arranjando ou desarranjando seus lugares sociais, suas disposições, suas formas de ser e de estar no mundo (LOURO, 2001, p. 28).

No ambiente das academias de lutas o reconhecimento requer percorrer uma trajetória bem demarcada até sua efetivação: a graduação ou faixa, por exemplo, atesta que o praticante já passou situações, como a superação das mais diversas dores, domínio das técnicas e o conhecimento do próprio corpo.

Movimento, Porto Alegre, v. 20, n. 3, p. 1153-1173, jul./set. de 2014. 
Por exemplo, na transição de graduações - presentes em modalidades como o Muay Thai, Jiu-jítsu, Capoeira, Judô, Taekwondo, dentre outras - está contida uma ideia de tradição, parte importante da memória tanto individual quanto coletiva, fortalecendo ainda mais a identidade grupal/tribal e o sentimento distintivo para com os que não percorressem o mesmo trajeto. De acordo com Louro (2001, p. 91) "[...] para dar a esses sujeitos o sentido de pertencimento à instituição ela terá de distingui-los dos outros, daqueles que estão fora de seus muros".

Por conseguinte, quanto maior a graduação, maior o poder moral na escala de hierarquização existente nas academias/equipes, especialmente dentro dos grupos, como evidencia o trecho a seguir:

Até a segunda faixa se aprendia a maioria golpes do Taekwondo. Depois da terceira faixa em diante aprendia o Muay Thai. Na primeira e na segunda faixa então você aprendia mais chutes. E a partir da terceira graduação em diante aí que vinham os golpes mais traumáticos de mãos, as cotoveladas e joelhadas, além do Boxe tradicional. (Entrevistado 5 - ex-lutador e mestre de Muay Thai - entrevista cedida em 08 nov. 2012).

Ainda de acordo com os agentes entrevistados, estar dentro dessa estrutura hierárquica marcial não significava só submissão ao mestre e aos companheiros mais graduados, mas também uma limitação ao acesso das técnicas no seio de um processo regrado de transmissão de conhecimentos específicos. A mudança de graduação, considerada como um rito de passagem, conferia ao praticante um indicador de progressão de status dentro do grupo mediante a comprovação do aprimoramento da qualidade de lutador no domínio das técnicas.

A figura do mestre é também apresentada na hierarquia como ocupante do posto mais alto, como autoridade máxima naquele microcosmo que é mundo das artes marciais, pois a ele é conferido o poder do conhecimento legítimo das técnicas a serem ensinadas. Ele exerce papel legitimador e fundamental no processo 
formativo, ou seja, nos treinamentos em geral. Por mais arbitrárias que pudessem parecer suas indicações, dificilmente alguém questionaria seu poder, como manifesta o relato a seguir:

Hoje eu paro e penso nas coisas que o nosso mestre mandava a gente fazer, um absurdo. A gente não tinha protetor de canela, de tórax, o capacete era todo rasgado e era um só. [...] E na movimentação podia dar joelhada no rosto, cotovelada, então todo dia alguém ia pro hospital [...] Tem coisa que não se treina, tem coisas que você não pode ensinar. (Entrevistado 3 - mestre de Muay Thai entrevista cedida em 20 out. 2012).

Se a autoridade do mestre era indiscutível, a falta da sua presença para guiar as ações do aluno poderia também promover uma possível desorientação. O afastamento do mestre foi atrelado como argumento para envolvimento em situações de brigas fora dos espaços das academias:

Quando você resolve as coisas "na mão" [brigas] é mais fácil. Era o momento que a gente vivia, nós éramos tudo [sic] novo, eu migrei pra cá e me afastei do meu mestre, não tinha uma orientação. $\mathrm{Eu}$ aprendia muito apanhando da vida, tive muito problema com briga, tive muito processo. (Entrevistado 6 - mestre de Capoeira - entrevista cedida em 09 nov. 2012).

Nesse processo de aquisição das técnicas de combate estão presentes aspectos que envolvem a construção social da masculinidade e sua constante (re)afirmação através de demonstrações públicas de violência e esta, por sua vez, [...] "pode ser uma forma de reforçar ou afirmar a masculinidade nas lutas de grupos" (CONNELL, 1997, p. 44, tradução livre).

A identificação do ser como masculino ocorre em situações polares de vitória ou fracasso por meio da aplicação de técnicas e força física adquiridas por meio de um processo, quase sempre, exaustivo. Os entrevistados enfatizam, muitas vezes, que o empenho nos treinamentos e a aquisição do domínio de movimentos

Movimento, Porto Alegre, v. 20, n. 3, p. 1153-1173, jul./set. de 2014. 
específicos de combate deveriam ser testados em situações competitivas reais. É apontado como fator motivador de brigas em diversos espaços (não aqueles específicos das academias) o fato de não haver possibilidades de disputas entre equipes rivais dentro de competições regradas, ficando os combates com regras restritos as suas próprias academias e entre os companheiros de grupo:

Curitiba tinha duas academias e eram rivais mesmo, não só dentro do esporte, mas rivais mesmo! E na época, não havia esses confrontos com ela. A gente pegava e lutava mesmo com os companheiros de treino. (Entrevistado 5 - exlutador e mestre de Muay Thai - entrevista cedida em 08 nov. 2012).

O povo aqui em Curitiba está acostumado com "trocação" e não existiam eventos. Eu, na minha época de lutador, lutava só dentro da academia nos exames de faixa porque não existiam eventos. (Entrevistado 2 - ex-lutador e mestre de Muay Thai - entrevista cedida em 6 out. 2012).

A realização de um combate para um lutador, entre outras coisas, representaria a oportunidade de demonstrar publicamente aspectos socialmente valorizados na construção de sua identidade, como percebe Louro (2001, p. 12) "reconhecer-se numa identidade supõe, pois, responder afirmativamente a uma interpelação e estabelecer um sentido de pertencimento a um grupo social de referência".

A capacidade de gerar violência, atrelada a outros aspectos associados ao gênero masculino, como a coragem de correr riscos, entrar no ringue e trocar golpes traumáticos, saciaria o "[...] desejo de ver reconhecida a sua excelência num determinado domínio" (GALTALDO; BRAGA, 2011, p. 889).

Ainda acerca desse aspecto, a agressividade instrumental das lutas tem sido frequentemente definida como um dado preexistente ou uma "energia" latente que precisaria ser extravasada. Os conflitos entre grupos e as relações de poder assumem um caráter quase de uma teoria do instinto primário em detrimento de algo 
socialmente aprendido e alimentado (WACQUANT, 2002). Essa autopercepção de uma identidade de lutador considerada masculina não está assegurada somente por atributos anatômicos, mas sim, pela filiação do indivíduo a um grupo e a determinados valores e condutas considerados masculinos (GASTALDO; BRAGA, 2011).

Há um processo de sociabilidade nas práticas que são produzidas, reproduzidas e reiteradas nesses espaços de pertencimento e da busca voluntária pelo risco. Ambos - o processo de sociabilidade e a busca do risco - apresentam-se em um contexto de violência. Em relação aos lutadores, a associação do exercício físico pesado para modelar o corpo através do fortalecimento dos músculos com um fim utilitário de torná-los preparados para as lutas e, sobretudo, a aquisição de técnicas de combate potencializam o ethos da disposição ao combate, existente no culto socialmente regulado da violência (WACQUANT, 2002, p. 33).

Esse ethos peculiar tem potencial de promover o desencadeamento de atitudes extremamente violentas motivadas pelo desejo de causar dor e sofrimento ao adversário em uma determinada situação de competição, seja institucionalizada ou não.

Existe, portanto, uma necessidade de provar a superioridade da sua modalidade e, consequentemente, de seu grupo de pertencimento, fazendo com que se extrapolem os espaços instituídos das academias, ocorrendo rixas em espaços públicos e privados inapropriados, naquilo que é chamado comumente de "briga de rua". Essa rivalidade violenta interpreta como legítimo o uso da brutalidade, sobretudo da agressão física, quando as tensões entre os grupos tornam-se extremas. Como destacam os entrevistados:

Existia muita rivalidade e quando eu cheguei aqui a Capoeira teve que se autoafirmar como luta, então teve muita gente que veio desafiar a gente, então a gente tinha que lutar. (Entrevistado 6 - mestre de Capoeira - entrevista cedida em 09 nov. 2012).

Movimento, Porto Alegre, v. 20, n. 3, p. 1153-1173, jul./set. de 2014. 
Eles se defrontavam na rua e um batia no outro. Eles andavam em grupo, acontecia na praia e também quando se encontravam pessoalmente. Estavam em dez, quinze, brigavam todo mundo. (Entrevistado 9-mestre de Capoeira e ex-lutador de "Vale-tudo" - entrevista cedida em 22 nov. 2012).

Esses confrontos eram pra mostrar "o meu é melhor do que o teu". Aqui foi briga de rua mesmo, eles estavam se digladiando onde se encontravam. (Entrevistado 7 - ex-lutador de "Vale-tudo" e Luta Livre - entrevista cedida em 14 nov. 2012).

Talvez existisse já um "Vale-tudo", digamos enrustido, através da briga de rua, que hoje seria briga de gangue.[...] O negócio deles era porrada, briga de rua. Era uma questão ideológica. (Entrevistado 1 - ex-praticante de Muay Thai entrevista cedida em 21 set. 2012).

Observa-se que o corpo masculino forte e treinado enfrenta constantes provações e "não levar desaforo para casa" significa não deixar os dons masculinos serem desfeitos ou ameaçados. A virilidade associada à demonstração de proezas másculas "[...] demarcam um dos maiores eixos através do qual os homens se situam e classificam outros homens" (CECCHETTO, 2004, p. 79).

Um dos envolvidos nos episódios de brigas de rua e também do primeiro "Vale-tudo" de Curitiba, relembra a rivalidade que desencadeou a instucionalização do "acerto de contas":

[...] Não tinha nível técnico nenhum, foi muito na louca mesmo. Na verdade, até o próprio árbitro, juiz, também não sabia o que fazer no momento ali porque não tinha regra, valia cabeçada, soco, cotovelada. (Entrevistado 9 - mestre de Capoeira e ex-lutador de "Vale-tudo" - entrevista cedida em 22 nov. 2012). 
O desregramento e a violência descontrolada demonstram que o modelo competitivo apresentado (aqui ainda não se pode definir tais embates como esporte) acabava sendo evidenciado por meio da valorização da força física no intuito de causar danos ao oponente e, sobretudo, na tentativa de evidenciar a supremacia de uma determinada técnica ou modalidade.

\section{Considerações finaIS}

O antigo "Vale-tudo" curitibano é parte constituinte da identidade individual (e coletiva) dos lutadores que participaram daquele período no qual, segundo os entrevistados, tudo era mais difícil: os treinamentos eram mais ríspidos e os testes corporais verdadeiros ritos de iniciação e/ou de passagem - eram contínuos.

As memórias apresentadas ao longo deste texto evidenciam sentidos atribuídos à constituição de um ethos próprio aos lutadores que participaram dos confrontos de rua, e também das lutas nos ainda precários e/ou improvisados ringues, demonstrando sua virilidade e seu senso de fidelidade ao grupo ao qual pertenciam.

A forma como os entrevistados apresentam um enquadramento memorial denota percepções e sentidos - conscientes e inconscientes - atribuídos ao passado. Interessante notar as estratégias de sobrevalorização de um passado tortuoso e austero e até excessivamente desregrado e violento, mas que rendeu ${ }^{11}$ frutos e que faz parte de uma fatia da história recente do desenvolvimento das Artes Marciais Mistas no cenário internacional por meio de seu processo de esportivização, ocorrido principalmente pela constante incorporação e adequação de regras.

A nostalgia que remete a um passado próximo cruel e sofrido é uma característica já bastante estudada por autores que se debruçaram sobre as características historiográficas da memória. Em relação aos rendimentos que tais práticas geraram, é possível

\footnotetext{
${ }^{11}$ Esse rendimento pode ser interpretado como a posição de destaque que alguns dos sujeitos aqui entrevistados ocupam, bem como do nome de suas novas academias ou "negócios".
}

Movimento, Porto Alegre, v. 20, n. 3, p. 1153-1173, jul./set. de 2014. 
invocar a ostensiva pesquisa de Pierre Bourdieu ${ }^{12}$ acerca dos diferentes tipos de capitais, suas formas de conversão e reconversão, e ainda seu valor em um mercado de trocas simbólicas, mas também concretas.

Como a memória aqui está sendo entendida como "possibilidade", sempre haverá outros modos e formas de abordagem em função do repertório teórico do qual se parte, mas principalmente em função do que foi relatado nas descrições memoriais.

\footnotetext{
${ }^{12}$ Há vários títulos nos quais Pierre Bourdieu aborda a noção de capital, suas diferentes formas de apresentação (conhecimento e reconhecimento) e suas várias possibilidades de conversão e reconversão. Entre essas obras estão:Questões de sociologia (1983); Poder simbólico (2007); A economia das trocas simbólicas (2013); A Produção da Crença: contribuição para uma economia dos bens simbólicos (2001), apenas para citar algumas.
}

Movimento, Porto Alegre, v. 20, n. 3, p. 1153-1173, jul./set. de 2014. 
The origins of "vale-tudo" in Curitiba-PR: memories on identity, masculinity and violence

Abstract: This paper aims to analyze how teachers (masters) and former fighters modalities fights and martial arts have their memories about the early days of practice that became known as "Vale-tudo" in Curitiba. Through theoretical procedures of Oral History was observed that the memorials fragments analyzed are not restricted to the interpretation of the origins of this practice, they are also traversed by discourses relating to the process of identity construction and constant tests of manhood. We conclude that memory established and this ethos has male violence as a central element - concrete and symbolic - that accompanies the formation of fighter.

Keywords: "Vale-tudo". Memory. Identity. Masculinity. Violence.

\footnotetext{
Los orígenes del "vale-tudo" en Curitiba-PR: memorias sobre la identidad, la masculinidad y la violencia.

Resumen: Este artículo tiene como objetivo analizar cómo tienen los profesores (maestros) y los exluchadores de modalidades de luchas y artes marciales sus recuerdos sobre los primeros días de práctica de lo que se conoció como "vale-tudo" en Curitiba. A través de los procedimientos teóricos de la Historia Oral se observó que los fragmentos analizados de las memorias no se limitan a la interpretación de los orígenes de esta práctica, sino que también están atravesados por discursos relacionados con el proceso de construcción de la identidad y por las pruebas constantes de la hombría. Llegamos a la conclusión de que la memoria establecida y este espíritu tiene a la violencia masculina como un elemento central -concreto y simbólico- que acompaña a la formación del luchador.

Palabras clave: "Vale-tudo". Memoria. Identidad. Masculinidad. Violencia.
} 


\section{REFERÊNCIAS}

ALBERTI, V. Manual de história oral. 3. ed. Rio de Janeiro: Editora FGV, 2005.

BOURDIEU, P. A dominação masculina. 5. ed. Rio de Janeiro: Bertrand Brasil, $2007 a$.

BOURDIEU, P. Economia das trocas simbólicas. São Paulo: Perspectiva, 2013.

BOURDIEU, P. Escritos de educação. 2. ed. Rio de Janeiro: Vozes, 1998.

BOURDIEU, P. O poder simbólico. Tradução de Fernando Tomaz. 10. ed. Rio de Janeiro: Bertrand Brasil, 2007b.

BOURDIEU, P. A produção da crença: contribuição para uma economia dos bens simbólicos. 2. ed. São Paulo: Zouk, 2004.

BOURDIEU, P. Questões de Sociologia. 7. ed. Rio de Janeiro: Marco Zero, 1983.

CECCHETTO, F. R. Violência e estilos de masculinidade. Rio de Janeiro: Editora FGV, 2004.

CONNELL, R. W. La organización social de la masculinidad. In: VALDÉS, Tereza y OLAVARRÍA, José (Ed.) Masculinidades y equidad de género en América Latina. Santiago: FLACSO/ISIS Internacional, Ediciones de las Mujeres, 1997. p. 31-48.

CORREIA, W.; FRANCHINI, E. Produção acadêmica em lutas, artes marciais e esportes de combate. Motriz, Rio claro, v. 16, n. 1, p. 1-9, jan./mar. 2010.

GASTALDO, E. L. Kickboxers: esportes de combate e identidade masculina. 1995. Dissertação (Mestrado em Antropologia Social) - Programa de Pós-Graduação em Antropologia Social, Universidade Federal do Rio Grande do Sul, Porto Alegre, 1995.

GASTALDO, É. L.; BRAGA, A. A. Corporeidade, esporte e identidade masculina. Estudos Feministas, Florianópolis, v. 19, n. 3, p. 875-893, set./dez. 2011.

LOURO, G. L. Gênero, sexualidade e educação: uma perspectiva pósestruturalista. Petrópolis: Vozes, 2001.

MAYER, A. F. Judô: valores e princípios incorporados ao longo da história. $157 \mathrm{f}$. Dissertação (Mestrado em Ciências do Movimento Humano) - Departamento de Educação Física, Universidade do Estado de Santa Catarina, Florianópolis, 2005.

NUNES, C. R. F. Corpos na arena: um estudo etnográfico sobre a prática das artes marciais combinadas. 255 f. Dissertação (Mestrado em Ciências do Movimento Humano) - Departamento de Educação Física, Universidade Federal do Rio Grande do Sul, 2004.

POLATO, A. L. Agressividade do lutador de Jiu Jitsu: perspectiva da imagem

Movimento, Porto Alegre, v. 20, n. 3, p. 1153-1173, jul./set. de 2014. 
As origens do "vale-tudo" na cidade de ...

social influenciada pela mídia. 111 f. Dissertação (Mestrado em Ciências da Motricidade) - Departamento de Educação Física, Universidade Estadual Paulista Júlio Mesquita Filho, Rio Claro, 2006.

POLLAK, M. Memória, esquecimento, silêncio. Revista Estudos Históricos, Rio de Janeiro, v. 2, n. 3, p.3-13, 1989.

POLLAK, M. Memória e identidade social. Revista Estudos Históricos, Rio de Janeiro, v. 5, n. 10, p. $200-212,1992$.

PORTELLI, A. Ensaios de história oral. São Paulo: Letra e Voz, 2010a.

PORTELLI, A. A filosofia e os fatos: narração, interpretação e significado nas memórias e nas fontes orais. Tempo, Rio de Janeiro, v. 1, n. 2, p. 59-72, 1996.

PORTELLI, A. História oral e poder. Mnemosine: Rio de Janeiro, v.6, n. 2, p. 0213, $2010 \mathrm{~b}$.

TEIXEIRA, A. C. E. M. "Esporte e violência no jiu-jítsu: o caso dos "pitboys". Dissertação (Mestrado) - Pontifícia Universidade Católica do Rio de Janeiro, Rio de Janeiro, 2008.

WACQUANT, L. Corpo e alma: notas etnográficas de um aprendiz de boxe. Rio de Janeiro: Relume-Damará, 2002.

Endereço para Correspondência

Universidade Federal do Paraná

Programa de Pós-graduação em Educação Física

Departamento de Educação Física

Rua Coração de Maria, 92, Campus Jardim Botânico - CEP 80210-132 - Curitiba/Paraná, Telefone: (41) 3360-4322 Fax: (41) 3360-4336

Recebido em: 25-09-2013

Aprovado em: 06-07-2014

Movimento, Porto Alegre, v. 20, n. 3, p. 1153-1173, jul./set. de 2014. 